\title{
Surface motion of active rock glaciers in the Sierra Nevada, California, USA: inventory and a case study using InSAR
}

\author{
L. Liu ${ }^{1}$, C. I. Millar ${ }^{2}$, R. D. Westfall ${ }^{2}$, and H. A. Zebker ${ }^{1}$ \\ ${ }^{1}$ Department of Geophysics, Stanford University, Stanford, CA, USA \\ ${ }^{2}$ USDA Forest Service, Pacific Southwest Research Station, Albany, CA, USA \\ Correspondence to: L. Liu (liulin@stanford.edu)
}

Received: 27 December 2012 - Published in The Cryosphere Discuss.: 23 January 2013

Revised: 7 June 2013 - Accepted: 11 June 2013 - Published: 18 July 2013

\begin{abstract}
Despite the abundance of rock glaciers in the Sierra Nevada of California, USA, few efforts have been made to measure their surface flow. Here we use the interferometric synthetic aperture radar (InSAR) technique to compile a benchmark inventory describing the kinematic state of 59 active rock glaciers in this region. In the late summer of 2007, these rock glaciers moved at speeds that range from $14 \mathrm{~cm} \mathrm{yr}^{-1}$ to $87 \mathrm{~cm} \mathrm{yr}^{-1}$, with a regional mean value of $53 \mathrm{~cm} \mathrm{yr}^{-1}$. Our inventory reveals a spatial difference: rock glaciers in the southern Sierra Nevada moved faster than the ones in the central Sierra Nevada. In addition to the regional mapping, we also conduct a case study to measure the surface flow of the Mount Gibbs rock glacier in fine spatial and temporal detail. The InSAR measurements over this target reveal (1) that the spatial pattern of flow is correlated with surface geomorphic features and (2) a significant seasonal variation of flow speed whose peak value was $48 \mathrm{~cm} \mathrm{yr}^{-1}$ in the fall of 2007, more than twice the minimum value observed in the spring of 2008. The seasonal variation lagged air temperatures by three months. Our finding on the seasonal variation of surface speed reinforces the importance of a long time series with high temporal sampling rates to detect possible long-term changes of rock glacier kinematics in a warming climate.
\end{abstract}

\section{Introduction}

Rock glaciers are tongue- or lobate-shaped landforms on high mountain slopes, typically consisting of mixtures of unconsolidated rock debris and ice. Rock glaciers are of geomorphic, climatic, and hydrological importance in alpine periglacial environments. They are visible indicators of permafrost and contribute to a major portion of mass transport of the alpine landforms (Barsch, 1977; Humlum, 2000; Brenning, 2005; Degenhardt, 2009). In addition, they preserve a long geological history and thus provide information and insights on paleoclimate (Clark et al., 1994; Humlum, 1998; Haeberli et al., 1999; Konrad et al., 1999; Harrison et al., 2008). Finally, they prolong internal ice melt and sustain surface runoff in dry years, acting as water reserves that are especially important in semi-arid mountain areas (Burger et al., 1999; Brenning, 2005; Croce and Milana, 2002; Millar et al., 2012).

Surface kinematics is a fundamental characteristic of rock glaciers (Haeberli et al., 2006). Active rock glaciers creep downslope cohesively as a consequence of the deformation of internal ice. Surface flow is related to regional forcing, including climatic conditions and local factors such as thickness, topographic relief, duration of solar radiation, lithology, and internal structures (Kääb et al., 2007). Therefore, temporal variation in surface kinematics sheds light upon changes in regional and local conditions.

Possible change of rock glacier flow in response to ongoing atmospheric warming is also an intriguing and important problem. Compared to glaciers, rock glaciers are believed to be less sensitive to rising temperature due to isolation of rock mantles (Clark et al., 1994; Barsch, 1996). However, there are also emerging observations suggesting that rock glaciers in the European Alps have increased flow rates since circa 1990 (e.g. Kääb et al., 1997; Krainer and Mostler, 2000; Delaloye et al., 2008; Nöetzli and Vonder Müehll, 2010).

Both field and remote sensing methods have been used to measure rock glacier surface flow. Repeat geodetic surveys 
map surface displacement at selected ground markers, usually a few years apart (e.g. Wahrhaftig and Cox, 1959; Barsch, 1996; Berger et al., 2004; Berthling et al., 1998; Konrad et al., 1999; Lambiel and Delaloye, 2004; Isaksen et al., 2000). Some recent efforts have installed permanent global positioning system receivers on rock glaciers for continuous monitoring (e.g. Limpach et al., 2011). Due to the remote locations of rock glaciers in high mountains, field observations are usually scarce and do not provide a complete view of rock glacier movement and processes. Remote sensing techniques such as repeat photogrammetry (e.g. Kääb et al., 1997; Kääb, 2002) and terrestrial laser scanning (Avian et al., 2009) have proved to be especially useful to fill the spatial gaps.

In contrast to optical sensors, microwave interferometric synthetic aperture radar (InSAR) measures ground deformation day or night in all weather conditions. The spatial extent of many space-borne SAR images is approximately $100 \mathrm{~km}$ wide and several hundreds of kilometers long. Most InSAR deformation maps have a spatial resolution as fine as $10 \mathrm{~m}$. These merits make InSAR a unique tool for measuring rock glacier flow including (1) regional mapping and (2) detailed case studies on individual rock glaciers. The latter capability has been demonstrated at rock glaciers around the world (Rott and Siegel, 1999; Nagler et al., 2002; Rignot et al., 2002; Kenyi and Kaufmann, 2003; Strozzi et al., 2004). Additionally, active rock glaciers have sparse vegetation cover, making them good InSAR targets as the temporal decorrelation problem due to vegetation changes is largely avoided (Zebker and Villasenor, 1992).

In this study we use the InSAR technique to map surface motion of rock glaciers in the Sierra Nevada of California, USA. Despite their abundance in this region, rock glaciers are largely overlooked. They have been recently brought to wider attention partly thanks to the inventory compiled by Millar and Westfall (2008) based on their field studies. This is hereafter referred to as the "MW database". Still, little is known about their kinematic states, let alone the long-term changes in surface flow.

Our first objective is to conduct a quantitative and nearly spatially complete assessment on the kinematic behaviors of the active rock glaciers in the Sierra Nevada. Using spaceborne InSAR data, we compile a georeferenced inventory to describe flow speed, aspect direction, mean slope and area of active motion of active rock glaciers in the region. To our knowledge, this is the first InSAR study on rock glaciers in the Sierra Nevada. Regional survey is difficult to accomplish logistically by field measurements. As a secondary product of the InSAR study, we are also able to identify rock glaciers based on their distinct kinematic behaviors from stable surroundings. Some of these rock glaciers have been overlooked in field studies due to their remoteness and their similar appearance to moraines and scree slopes (Millar and Westfall, 2008). For the latter reason, it is also difficult to spot a few rock glaciers on optical remote sensing images. Our second objective is to focus on a single target, the Mount Gibbs rock glacier, to image its surface motion at a fine spatial resolution and investigate its seasonal variation.

\section{Rock glaciers in the Sierra Nevada of California}

\subsection{Overview}

The Sierra Nevada is a major mountain range located between the Central Valley and the Basin and Range province in California. It has Mediterranean and semi-arid climates, characterized by warm dry summers and cool wet winters. Snow precipitation occurs between November and May, with a modest late winter peak (Serreze et al., 1999). The entire region was heavily glaciated during the Pleistocene (Clark and Gillespie, 1997). A few small glaciers and persistent snow fields are scattered at cirques in the high mountains. Weathered rock is abundant, especially along metamorphic exposures of the eastern escarpment.

Rock glaciers and related landforms are common throughout cirques and valleys of the central and southern parts of the range. Our study area extends from north of Bridgeport to Lone Pine as shown in Fig. 1. Millar and Westfall (2008) mapped more than 280 rock glaciers in this area and compiled a database that is archived at the National Snow and Ice Data Center (http://nsidc.org/data/ggd652.html). Most of these rock glaciers are clearly visible in remote sensing optical imagery such as Google Earth images and air photos (more in Sect. 4.1 and Fig. 3). According to their different locations, origins, and shapes, Millar and Westfall (2008) further grouped the rock glaciers into two classes: cirque rock glaciers and valley wall rock glaciers. Cirque rock glaciers originate in high cirques and flow parallel to the valley axis as long-lobed debris bodies. They often have an ice or snow field at the cirque wall and arcuate flow lines on the debris surface. The MW database lists 184 cirque rock glaciers, $67 \%$ of which are active and have a mean elevation of $3390 \mathrm{~m}$ and a mean size of $20 \mathrm{ha}$. Valley wall rock glaciers, instead, occur on valley walls and are characterized by wide wedge-shaped structures. The MW database includes 105 valley rock glaciers, $61 \%$ of which are active and have a mean elevation of $3292 \mathrm{~m}$ and a mean size of $3 \mathrm{ha}$, much smaller than the cirque rock glaciers.

\subsection{Mount Gibbs rock glacier}

The Mount Gibbs rock glacier is centered at $37^{\circ} 53^{\prime} 44^{\prime \prime} \mathrm{N}$, $119^{\circ} 12^{\prime} 13^{\prime \prime} \mathrm{W}$ and is located in Gibbs Canyon along the eastern escarpment of the Sierra Nevada. Its ground and aerial photos are shown in Figs. 2 and 5a, respectively. This tongue-shaped rock glacier is approximately $700 \mathrm{~m}$ long in its flow direction and $300 \mathrm{~m}$ wide. Its geometry suggests that the rock glacier flows downslope initially in a N-NE direction and then bends toward the NE and ENE. Its head is a bowl-shaped cirque wall surrounded by Mount Gibbs (3893 m a.s.1.) and Mount Dana (3980 m a.s.1.). 


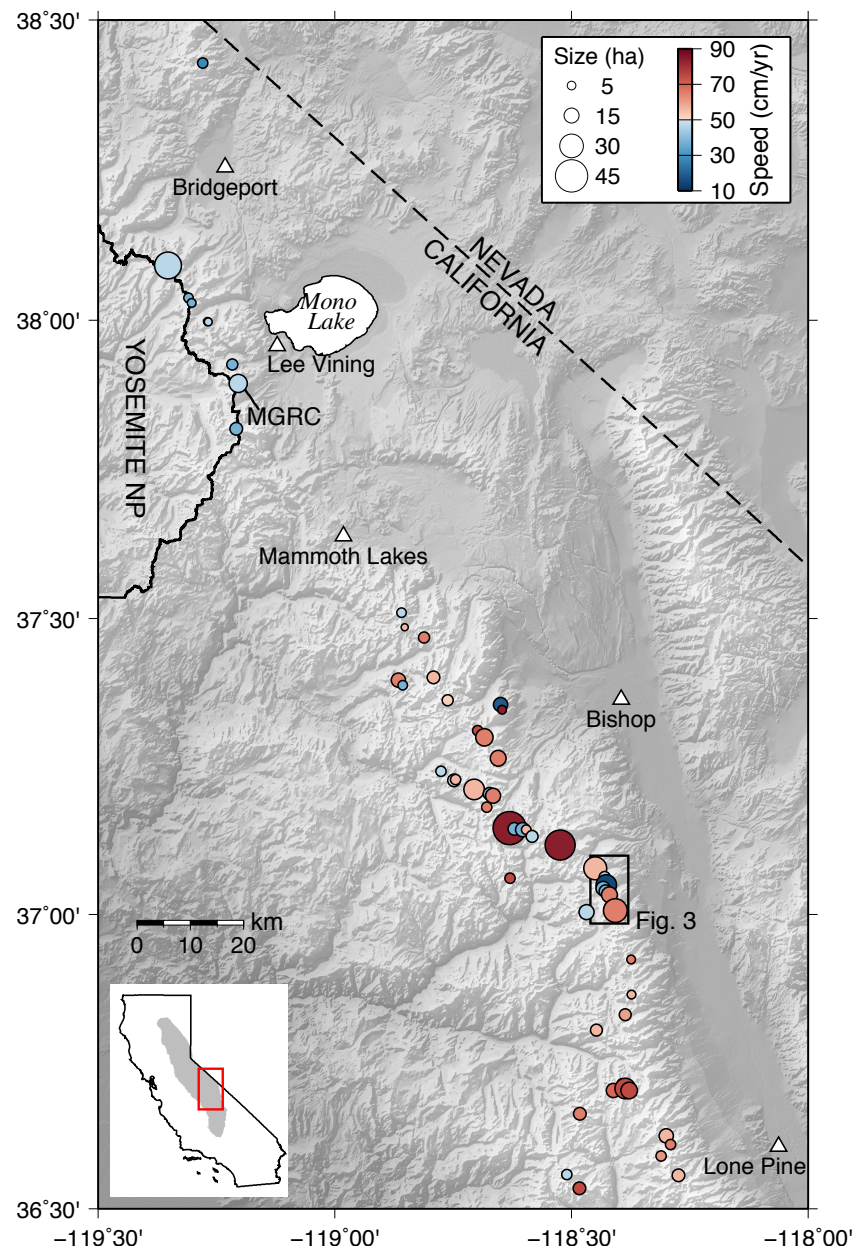

Fig. 1. Map of the study area in the central and southern Sierra Nevada of California, USA. Circles are active rock glaciers based on our InSAR measurements. The size and color of the circles represent the size and speed of the rock glaciers, respectively. The flow speed estimates are for the late summer of 2007. "MGRC" stands for the Mount Gibbs Rock Glacier. The black box outlines the area shown in Fig. 3. The inset map of California shows the Sierra Nevada in gray and the location of the study area as a red box.

A small glacier is perched in the adjacent and hanging cirque to the east of the rock glacier. Complex meta-volcanic and meta-sedimentary rocks form mountains of this region (Kistler, 1966). The rock glacier surface is covered by angular and poorly sorted graywackes, which are gray-colored meta-sedimentary rocks. Transverse furrows and longitudinal ridges are visible along two lobes in the middle and lower parts. The terminus of the rock glacier is an over-steepened face and forms the southwest shore of Kidney Lake. To the east of the rock glacier terminus, unconsolidated sediment extends into the lake and forms the lake's concave shoreline. This material is not part of the rock glacier but derived from the glacier at the peak of Mount Gibbs.

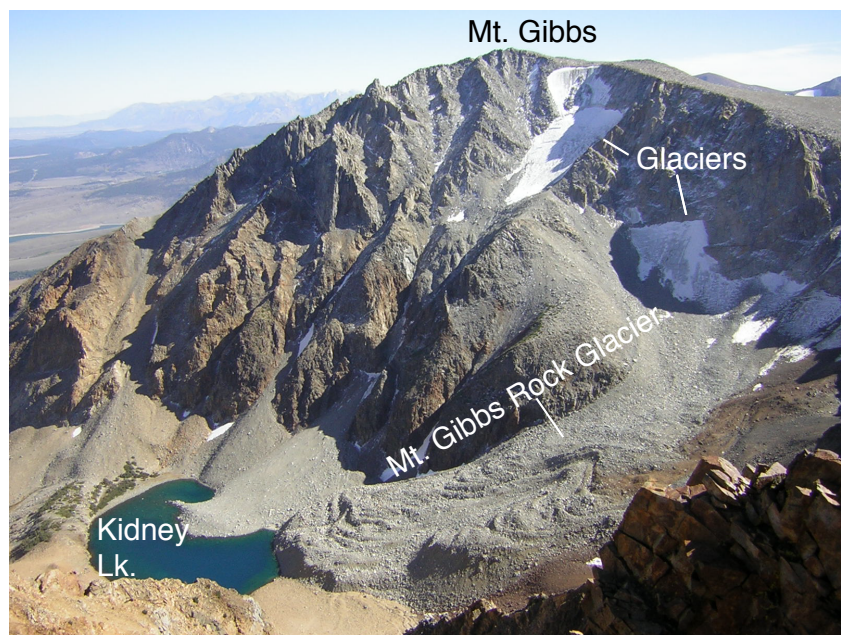

Fig. 2. The Mount Gibbs rock glacier from the shoulder of Mount Dana looking south (Photo: C. Millar).

We choose the Mount Gibbs rock glacier for a detailed kinematic study because of several reasons. Although it is similar to other active cirque rock glacier in the MW database in elevation and size, the Mount Gibbs rock glacier has a complex geometry and thus an interesting target for mapping surface flow at fine spatial resolution. From the perspective of InSAR processing (see more in Sect. 3.2), this rock glacier is ideal because of its NE flow direction, moderate flow speed, and large debris-covered area. Practically, radar images from two satellite tracks were acquired continuously over this rock glacier (see Sect. 3.1), making it possible to conduct a detailed time series study.

\section{Methods}

In this section, we first present technical details of InSAR processing for the case study on the Mount Gibbs rock glacier (Sect. 3.1). Then we describe a similar but simplified strategy for the regional survey and also list criteria for including an active rock glacier in our inventory (Sect. 3.2).

\subsection{InSAR data and processing for case study}

We apply InSAR processing using a motion-compensation strategy (Zebker et al., 2010) to the Phased Array type Lband Synthetic Aperture Radar (PALSAR) data acquired by the Japanese Advanced Land Observing Satellite (ALOS). By measuring phase differences between two radar images taken at different times, InSAR constructs an interferogram that maps ground surface displacement along the line-ofsight (LOS) direction during the time interval of the two images. To maximize the temporal sampling rates of ground deformation from spring 2007 to spring 2008, we use the PALSAR data acquired along two ascending paths: Path 216/Frame 750 and Path 217/Frame 740. Unfortunately, 
Table 1. Interferograms made from the case study on the Mount Gibbs rock glacier. Names of interferograms are in the format "yyyymmdd-yyyymmdd", after the dates of the two SAR scenes used. Column "B perp" lists the perpendicular baselines of the interferograms.

\begin{tabular}{lccc}
\hline Interferogram & $\begin{array}{c}\text { Time span } \\
(\text { days })\end{array}$ & $\begin{array}{c}\text { B perp } \\
(\mathrm{m})\end{array}$ & Path/Frame \\
\hline $20070402-20070518$ & 46 & -286 & $216 / 750$ \\
$20070402-20070703$ & 92 & 92 & $216 / 750$ \\
$20070402-20070818$ & 138 & 315 & $216 / 750$ \\
$20070518-20070703$ & 46 & 378 & $216 / 750$ \\
$20070518-20070818$ & 92 & 601 & $216 / 750$ \\
$20070703-20070818$ & 46 & 223 & $216 / 750$ \\
$20070904-20071205$ & 92 & 349 & $217 / 740$ \\
$20071003-20080103$ & 92 & 354 & $216 / 750$ \\
$20071020-20071205$ & 46 & 109 & $217 / 740$ \\
$20071020-20080120$ & 92 & 534 & $217 / 740$ \\
$20071205-20080120$ & 46 & 424 & $217 / 740$ \\
$20080103-20080520$ & 92 & 1218 & $216 / 750$ \\
\hline
\end{tabular}

no descending path PALSAR scenes were acquired by the ALOS satellite over this area. Scenes acquired in other years are not available to us either. We take a spatial average of every two pixels in the azimuth direction on each interferogram to achieve a ground resolution of approximately $10 \mathrm{~m}$ by $10 \mathrm{~m}$. Accordingly, we use a $1 / 3$ arc-second (approximately $10 \mathrm{~m}$ ) digital elevation model (DEM) from the USGS National Elevation Database to remove the topographic contribution. The DEM was produced using data acquired during 1999 and 2001 and has a quoted vertical accuracy of $3 \mathrm{~m}$ (Gesch et al., 2002). The possible elevation changes between DEM date and PALSAR acquisitions could cause InSAR deformation errors that are linearly correlated with the perpendicular baseline. Such topographic errors are estimated and removed in time series analysis (see below).

We produce a total of 12 interferograms and list them in Table 1. All interferograms have a short time span as we want to minimize InSAR phase decorrelation due to fast ground motion and to better detect seasonal variability of ground motion. The repeat orbit cycle of the ALOS satellite limits the shortest time span to 46 days. We use the SNAPHU software (Chen and Zebker, 2002) for phase unwrapping, i.e. the process to reconstruct the absolute phase from the InSAR observable: the $2 \pi$ modulus of the absolute phase. We also choose a reference point $\left(37^{\circ} 54^{\prime} 0^{\prime \prime} \mathrm{N}, 119^{\circ} 11^{\prime} 44^{\prime \prime} \mathrm{W}\right)$ outside the rock glacier where we assume zero displacement.

To determine the ground surface motion, we project the InSAR-measured LOS displacements onto the downslope direction, assuming that surface-parallel flow follows the steepest slope direction on the rock glacier surface. The InSAR LOS vector is determined by two angles: the heading angle of satellite flight path, denoted as $\alpha$, and the incidence angle $\theta_{\text {inc }}$ (i.e. the angle between the incident radar waves and the direction normal to the ground surface). Along both paths, the heading angles are the same: $13.5^{\circ}$ westward from north. Within the rock glacier area, the incidence angles are $37.5^{\circ}$ and $40.3^{\circ}$ for Paths 216 and 217, respectively. We use the DEM to calculate local slope angle $\theta_{\text {slp }}$ and azimuth angle $\beta$ and then use the following mapping function to convert the LOS displacement $\left(D_{\mathrm{LOS}}\right)$ to the downslope displacement $(D)$ :

$$
D=\frac{D_{\mathrm{LOS}}}{\sin (\alpha-\beta) \sin \theta_{\mathrm{inc}} \cos \theta_{\mathrm{slp}}+\cos \theta_{\mathrm{inc}} \sin \theta_{\mathrm{slp}}} .
$$

For each interferogram, we divide the InSAR-estimated downslope displacement by the time interval and obtain the speed with $\mathrm{cmyr}^{-1}$ as units. We note that all of the speed estimates provided in this study are for specific periods, not annual averages.

We also calculate time series of surface speed at selected high coherence points. From each set of geocoded interferograms grouped according to their paths, we use the small baseline subset inversion method (Berardino et al., 2002) to estimate surface speed during two consecutive acquisitions as well as topographic errors. We then combine these two sets of speed estimates to obtain a continuous time series from spring 2007 to spring 2008. We assume that the tropospheric artifacts are uniform within this small area so that we do not apply any atmospheric filtering in the time series inversion.

\subsection{Making a regional rock glacier inventory using InSAR}

For regional mapping, we identify the rock glaciers by manually inspecting moving features on interferograms. Instead of time series analysis using multiple interferograms, we only construct one interferogram from each ALOS PALSAR frame (roughly $100 \mathrm{~km}$ by $70 \mathrm{~km}$ ). Our study area (Fig. 1) is approximately $240 \mathrm{~km}$ by $150 \mathrm{~km}$ and is completely covered by five frames: Frames 720, 730, and 740 in Path 216 and Frames 740 and 750 in Path 217. For each frame in Path 216, we construct one interferogram by applying the same InSAR processing methods described in Sect. 3.1 to the PALSAR data acquired on 18 August 2007 and 3 October 2007. Similarly for Path 217, we construct one interferogram for each frame using the data acquired on 4 September 2007 and 20 October 2007. Figure 3a shows a portion of the Path 216/Frame 730 interferogram as an example that reveals moving rock glaciers standing out from surrounding landforms. For comparison, we also show optical images taken in the summer of 1999 in Fig. 3b-d, in which rock glaciers appear similar to their surroundings.

Constrained by the capability of InSAR for mapping small targets in mountain areas, there are a few limitations on the size, flow speed, and location of a rock glacier to be included in our inventory. First, InSAR can only measure surface flow over the debris-covered area where the interferometric 

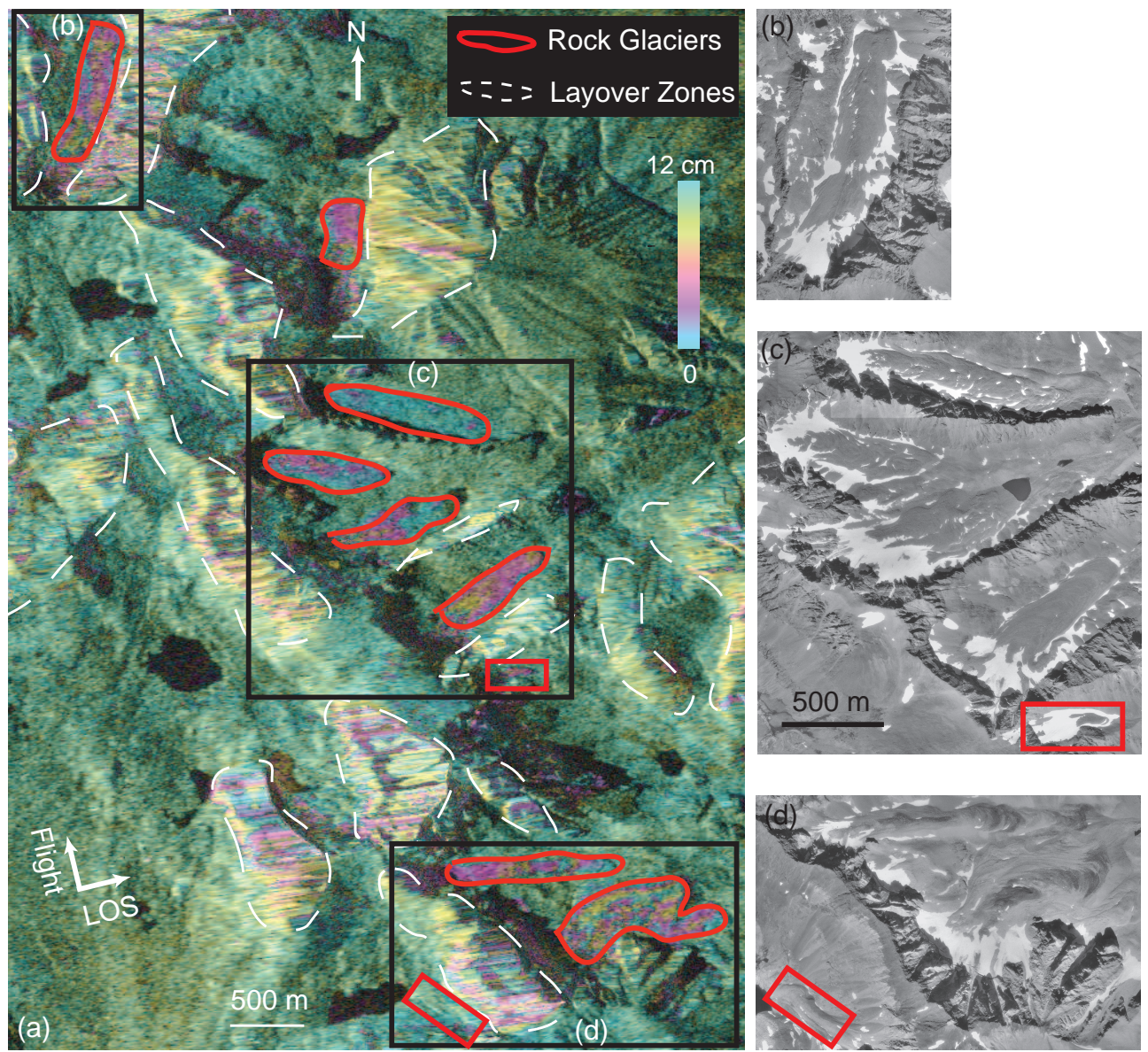

Fig. 3. (a) Wrapped and geocoded PALSAR interferogram spanning 18 August 2007 to 3 October 2007 (Path 216, Frame 730). Background is the radar intensity image. Actively moving areas of rock glaciers are outlined by red polygons. Red boxes outline two rock glaciers not included in our inventory (see Sect. 3.2). White dashed polygons outline radar layover zones. Satellite flight and line-of-sight (LOS) directions are plotted as perpendicular vectors. (b-d) are aerial photos of the areas defined in (a). These photos were taken in the late summer of 1998 and produced by the USDA Geospatial Service and Technology Center. All photos are to the same scale shown in (c).

coherence is sufficiently high. Decorrelation in interferometry phase is common at the glacier-covered head due to fast ground motion. Second, the debris-covered area of a rock glacier must be larger than 2 ha to be reliably identified. For instance, the Fig. 3a interferogram barely resolves surface motion over the small rock glacier outlined by the red box in Fig. 3c. Third, at each rock glacier, the displacement component of the total phase must be significantly larger than decorrelation noise, here assumed $1 \mathrm{~cm}$. For a 46-day-span interferogram, this lower bound on the flow speed is equivalent to $10 \mathrm{~cm} \mathrm{yr}^{-1}$. Fourth, we are unable to map any rock glaciers located within the radar shadow or layover zones that face the radar illumination. In the viewing geometry of ascending frames used in this study, layover zones are on the western slopes and appear as bright stripes (outlined in Fig. 3a). Lastly, also limited by the viewing geometry, we are unable to identify any rock glaciers moving parallel to the satellite flight direction using the conventional cross-track InSAR technique. This is likely the reason that the rock glacier outlined by the red box in Fig. 3d appears not to be moving in the interferogram and thus is excluded from our inventory.

We also use additional data, including the MW database and Google Earth images, as aids to identifying rock glaciers from interferograms. Interferograms simply measure surface motion; they alone cannot tell the origin of surface motion. In addition to rock glaciers, surface motion may occur at several other types of geomorphic features in the Sierra Nevada, including soil solifluction by mass wasting, boulder streams, debris flows, landslide slumping, avalanches, rock fall/slides, and normal glaciers. Of these features, soil solifluction and boulder streams are akin to rock glaciers, and their motion can be generalized as periglacial surface creep. Locations for soil solifluction and boulder streams are listed in the MW database, which is used to distinguish these features from our rock glacier inventory. All other features except for small glaciers typically move at speeds at least one order of magnitude higher than rock glaciers, and therefore lose coherence in our 46-day-span ALOS interferograms. Glaciers can be 


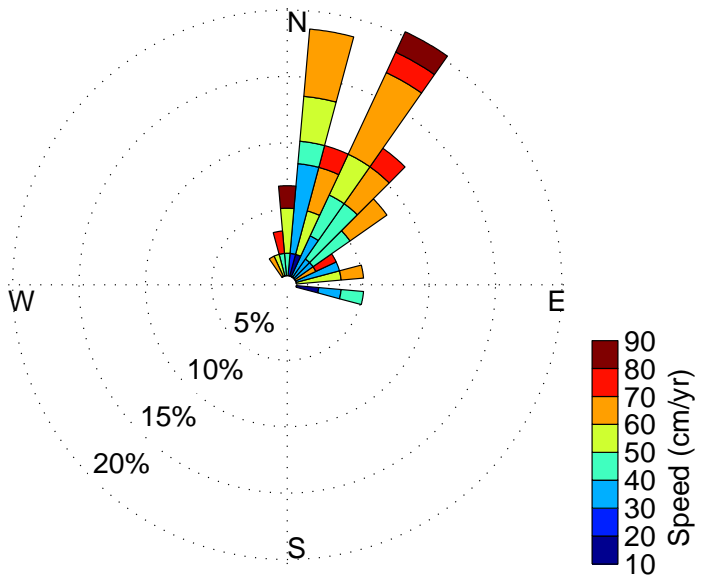

Fig. 4. Histogram of rock glacier flow aspects and 2007 latesummer speeds, plotted as a wind rose diagram. The radius of each triangle represents the frequency of the rock glacier aspects within each bin (10 degrees wide). Each triangle is subdivided into colorcoded bands that show flow speed ranges.

easily separated from rock glaciers by visually inspecting optical remote sensing products such as Google Earth images. Regardless, features smaller than 2 ha are excluded from our inventory.

For each identified active rock glacier, our inventory lists the size, flow speed and aspect direction based on the InSAR measurements, and the mean slope and elevation based on the DEM. Similar to the Mount Gibbs rock glacier study, we choose a local reference point near but outside each rock glacier to calibrate the flow speed measurements. Using the geocoded interferograms, we measure the dimensions along and across flow direction of each active rock glacier, whose area is not always the same as the area of apparently active moraines shown on optical images. Similar to the Mount Gibbs rock glacier study, we use site-wise incidence angles and mean local surface slopes to convert the InSAR LOS displacement into downslope motion using Eq. (1) for all rock glaciers. We use the measured speed at the center of each rock glacier in the late summer of 2007 to represent its kinematic state.

\section{Results}

\subsection{Regional inventory}

Our database describes the kinematic states of 59 active rock glaciers in the central and southern Sierra Nevada. Their speeds in late summer of 2007 and sizes are plotted in Fig. 1. We provide the complete inventory in the Supplement, including a Google Earth KMZ file and a spreadsheet that provides all quantitative information. Table 2 summarizes the regional mean values of major parameters. The mean speed was $55 \mathrm{~cm} \mathrm{yr}^{-1}$, with the fastest one moving at $84 \mathrm{~cm} \mathrm{yr}^{-1}$
Table 2. Summary of the active rock glaciers in the Sierra Nevada based on InSAR and comparisons with the "active" cirque rock glaciers in the Millar and Westfall (2008) (MW) database. The term "active" used by the MW database is based on the geomorphological and hydrological features (see Sect. 4.1). The flow speed estimates are for the late summer of 2007.

\begin{tabular}{|c|c|c|}
\hline & InSAR & MW \\
\hline Number & 59 & 67 \\
\hline Mean elevation (m) & 3551 & 3390 \\
\hline Elevation range $(\mathrm{m})$ & $3077-3787$ & 2673-3901 \\
\hline Mean size (ha) & 13 & 20 \\
\hline Size range (ha) & $3-46$ & N/A \\
\hline Mean length (m) & 624 & N/A \\
\hline Mean width (m) & 201 & N/A \\
\hline Mean length-to-width ratio & 3.3 & N/A \\
\hline Mean flow speed $\left(\mathrm{cm} \mathrm{yr}^{-1}\right)$ & 53 & N/A \\
\hline Flow speed range $\left(\mathrm{cm} \mathrm{yr}^{-1}\right)$ & $14-87$ & N/A \\
\hline
\end{tabular}

and the slowest one moving at $15 \mathrm{~cm} \mathrm{yr}^{-1}$. They have a mean elevation of $3551 \mathrm{~m}$ and a mean size of $13 \mathrm{ha}$.

Our regional survey reveals several important spatial patterns of rock glacier kinematics in the Sierra Nevada. The histogram of the azimuthal distribution (Fig. 4) indicates a pronounced dominance of rock glaciers facing the N-NE direction. This is common for rock glaciers and normal glaciers that form in the Northern Hemisphere because of the solar radiation aspect. Snow accumulation due to drifts from SW winds and snow avalanching in this region may also contribute to such N-NE dominance.

The regional map (Fig. 1) shows that active rock glaciers tend to cluster to each other, implying a significant influence of regional conditions such as climate and topography on their occurrence. There is a spatial gap in the mountain areas near Mammoth Lake where elevation is lower than $3000 \mathrm{~m}$. In the late summer of 2007 , rock glaciers in the southern Sierra Nevada moved at a mean speed of $56 \mathrm{~cm} \mathrm{yr}^{-1}$, faster than the ones in the central Sierra Nevada whose mean speed was $39 \mathrm{~cm} \mathrm{yr}^{-1}$. Considering the standard deviation values of these two sub-regional groups: $15 \mathrm{~cm} \mathrm{yr}^{-1}$ for the southern area and $8 \mathrm{~cm} \mathrm{yr}^{-1}$ for the central area, we conclude that the spatial difference in mean speeds is significant. We speculate that such a regional difference, which is also visually evident in Fig. 1, is related to the topographic relief. Investigation of the underlying causes for the regional difference in rock glacier speed is a subject of future work.

Another spatial contrast is that rock glacier speeds were less uniform in the southern area than in the central Sierra Nevada. Within some valleys in the southern area, such as the ones shown in Fig. 3, we observe a significant spatial variation in kinematic behaviors. It suggests strong influences of local factors such as thickness, ice content, hydrological conditions, and debris content on surface speed. 

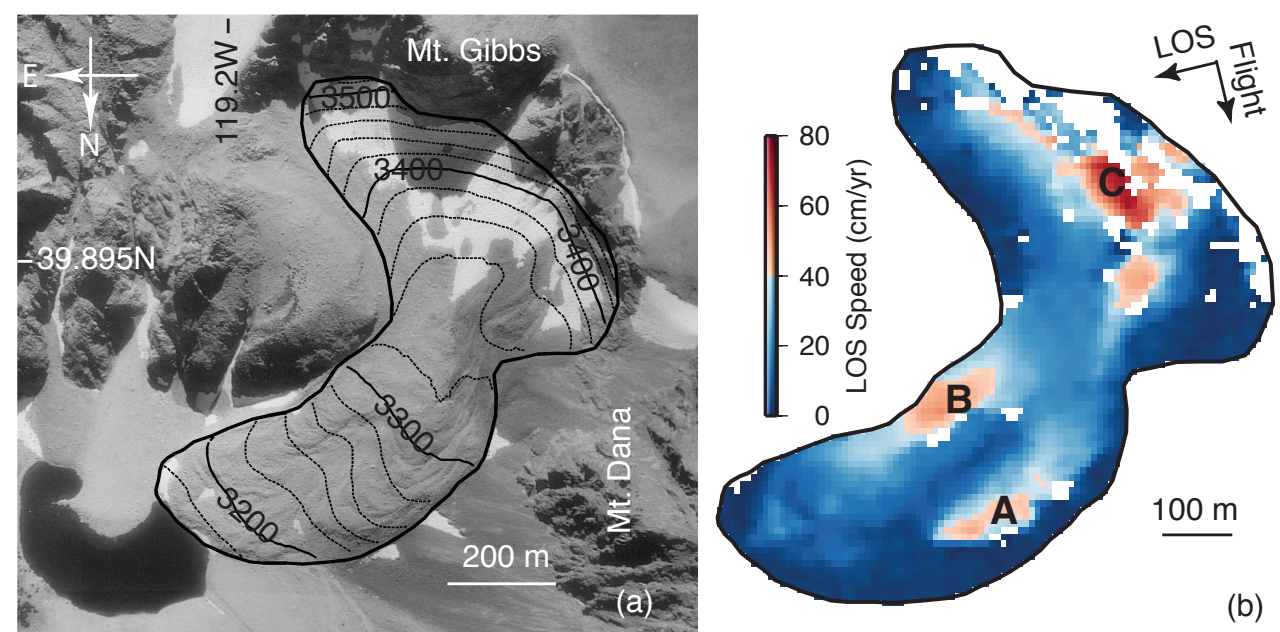

Fig. 5. (a) Aerial photo of the Mount Gibbs rock glacier, taken on 25 September 1993. Rock glacier boundary is roughly outlined by the solid black line. Dashed lines are topographic contours spaced at $20 \mathrm{~m}$. (b) InSAR line-of-sight speed during 4 September 2007 and 5 December 2007. White areas within the black boundary are places of low interferometric coherence. "A", "B", and "C" mark the center of fast-moving areas. Both (a) and (b) are rotated clockwise by 180 degrees to match the viewing geometry of Fig. 2. North and east directions are denoted in (a).

We compare our inventory with the MW database in terms of rock glacier classes and locations. All of our identified active features fall into the cirque rock glacier class defined by Millar and Westfall (2008). However, only 14 (or $24 \%$ ) of them are collocated with the "active" ones in the MW database. Millar and Westfall (2008) used the term "active" based on the geomorphic and hydrological features, which may not all be actively moving. Our mapping method using InSAR is a direct measurement of surface flow motion and thus ensures that the identified targets are moving at a minimum speed of $10 \mathrm{~cm} \mathrm{yr}^{-1}$. In addition, 16 active cirque rock glaciers in the MW database are not included in our inventory because they are smaller than 2 ha. We exclude 12 of MW's active rock glaciers, for instance, 7 in the Piute Pass Glacier divide $\left(37.23^{\circ} \mathrm{N}, 118.75^{\circ} \mathrm{W}\right)$, because they are either in the radar shadow zones or completely lose radar coherence due to persistent snow cover. However, on the positive side, our inventory includes 44 active rock glaciers that are not identified in the MW database from field work. For instance, within the region of Fig. 3, the MW database only includes one rock glacier (i.e. the South Fork rock glacier as shown in Fig. 3b). Overall, we conclude that our inventory based on InSAR and the MW database are complementary to each other, and together they provide a more complete and valuable dataset.

\subsection{Surface flow of the Mount Gibbs rock glacier and its phase lag behind air temperature}

In this subsection, we present the InSAR results on the surface flow at the Mount Gibbs rock glacier. We first show the spatial variability that is correlated with surface geomorphic features. We then provide a time series of surface flow speed

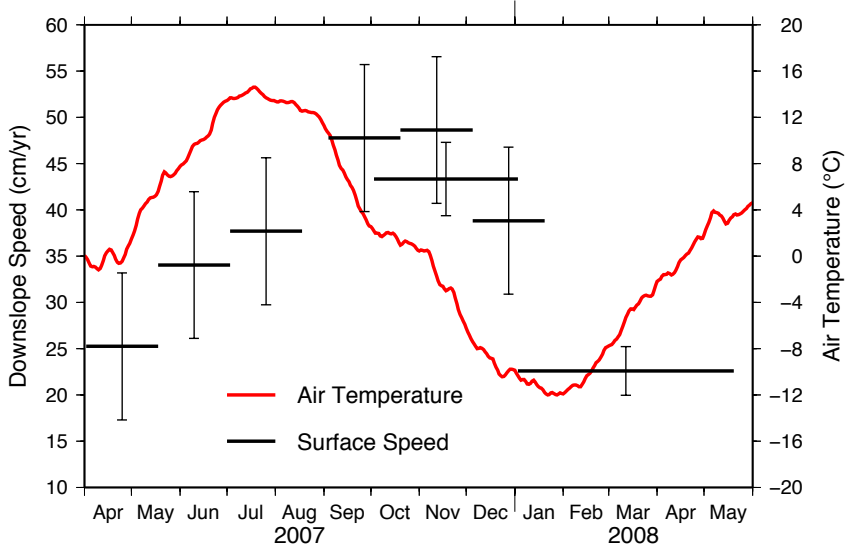

Fig. 6. Time series of the smoothed air temperature (red line) and the InSAR-estimated downslope speed (horizontal bars) at the marker "A" shown in Fig. 5b. The extent of each horizontal bar represents the period from which the speed is estimated (see Sect. 3.1). The vertical error bars are the $1 \sigma$ uncertainties of the measured speed.

showing its seasonal variation during 2007-2008 and its delay behind air temperature.

On individual targets, InSAR provides a more spatially complete assessment of the surface flow than field measurements. Figure $5 \mathrm{~b}$ shows the InSAR LOS speed over the Mount Gibbs rock glacier between 4 September 2007 and 5 December 2007. It clearly maps out two rapidly flowing lobes (centered at "A" and "B") at speeds of $\sim 50 \mathrm{~cm} \mathrm{yr}^{-1}$ and starting from the middle section of the rock glacier. Along both lobes, InSAR LOS speed decreases towards the 
rock glacier terminus. Such gradients in speed correlate well with surface ridges and furrows and suggest that these are geomorphic features caused by longitudinal compression. Figure $5 \mathrm{~b}$ also shows rapid surface motion $\left(>60 \mathrm{~cm} \mathrm{yr}^{-1}\right)$ near the head of the rock glacier (centered at "C"), although we cannot distinguish if this is motion of an ice field or rock debris beneath snow cover. Additionally, this InSAR map reveals stable areas such as the southeast flank and the depression area between the two flowing branches.

Our time series analysis shows a strong seasonal variation of surface speed. In Fig. 6, each horizontal bar represents the mean downslope speed at the marker "A" in Fig. 5b during the two consecutive PALSAR images in the same path. The vertical error bars show the $1 \sigma$ uncertainties. The time series shows that the surface flow speed was low in the spring, gradually increased throughout the summer, peaked in the fall at $48 \mathrm{~cm} \mathrm{yr}^{-1}$, and then abruptly decreased in the winter, reaching the minimum of $22 \mathrm{~cm} \mathrm{yr}^{-1}$ in the following spring. This seasonal variation had a phase lag behind the annual cycle of air temperature shown as the red line in Fig. 6 . Taking into account the uncertainties and the temporal intervals of speed estimates, we estimate that the phase delay value ranges from one to four months, with a median of three months. We calculate the air temperature at the rock glacier using 2007-2008 daily mean air temperature records measured at Lee Vining (see its location in Fig. 1) and a temperature lapse rate of $-6.5^{\circ} \mathrm{C} \mathrm{km}^{-1}$ (Lundquist and Cayan, 2007; Millar and Westfall, 2008) to account for the elevation difference. We apply a one-month moving average filter to smooth the daily records. This estimated temperature is consistent with the field measurements (Millar et al., 2012) and the Parameter-elevation Regressions on Independent Slopes Model (PRISM) outputs (Daly et al., 1994).

Limited by data availability, we are only able to conduct such a time series study for the 2007-2008 season. Nevertheless, our study adds one more finding to the few observations on seasonal variation of rock glacier speed (Haeberli, 1985; Arenson et al., 2002; Kääb et al., 2007; Perruchoud and Delaloye, 2007; Ikeda et al., 2008). Both the magnitude and the temporal delay of seasonal variability behind air temperature are comparable with the ground-based measurements at the Muragl (Arenson et al., 2002; Kääb et al., 2007) and the Becs-de-Bosson rock glaciers (Perruchoud and Delaloye, 2007) in the Swiss Alps.

The exact cause(s) of the seasonal variations in speed at the Mount Gibbs rock glacier is unclear. It might be partly due to the changes of rock glacier mechanical strength and rheology with ground temperature. We model the thermal diffusion of ground warming and the increase of the creep parameter of rock glacier materials using the same method of Kääb et al. (2007). We find that the modeled seasonal variation in surface speed is approximately $5 \%$ of the annual mean, much smaller than the InSAR-observed $50 \%$ variations. Kääb et al. (2007) found a similar discrepancy between the in situ observations and the modeled speed variations that are solely driven by thermal diffusion. Even if we include a thin layer of highly deformable frozen material (Wagner, 1992; Arenson et al., 2002) in the flow model, the modeled seasonal variation is still less than $10 \%$.

\section{Discussion}

\subsection{Strengths and weaknesses of the InSAR-based rock glacier inventory}

We have demonstrated that InSAR provides quantitative information on the surface flow of rock glaciers on a spatial scale of a major mountain range. The InSAR survey reveals spatial patterns of rock glacier kinematics and provides benchmark information for studying the relationship between regional and local forcing conditions and rock glacier speed and for long-term monitoring efforts. The InSAR survey also quantifies rock glacier speed, which is difficult to measure in the field. Inventory mapping using InSAR is also more complete than optical studies that are usually limited by cloud covers. In fact, InSAR and optical remote sensing techniques are complementary as the latter can provide twodimensional velocities at even higher (e.g. sub-meter) spatial resolution (e.g. Roer et al., 2005) and is not limited by the layover problem (see below).

However, our InSAR-based inventory is still incomplete. As explained in Sect. 3.2, our inventory only includes rock glaciers that are larger than $2 \mathrm{ha}$, move faster than $10 \mathrm{~cm} \mathrm{yr}^{-1}$, are located outside radar layover (western slopes) and shadow zones, and flow non-parallel to the satellite flight direction. The lower bound on flow speed could be relaxed using interferograms spanning longer periods, provided that high coherence is maintained. The location constraints are not severe in the Sierra Nevada because most active rock glaciers are located on the eastern (leeward) slopes.

Our InSAR-based flow speed estimates are not free of errors. Deformation signals in one interferogram are contaminated by decorrelation noises, atmospheric artifacts, snow cover (more discussion below), and DEM errors. However, these errors are not correlated in time and could be reduced using multiple interferograms. Additionally, using the 2007 late-summer interferograms, instead of taking annual averages, may overestimate the kinematic states of rock glaciers, as the case study on the Mount Gibbs rock glacier suggests that the annual-mean speed is likely smaller than the latesummer speed.

Temporal changes of snow cover and depth may cause (1) the InSAR decorrelation problem due to changes of surface dielectric properties and (2) InSAR phase errors due to refraction of radar waves in snow (Guneriussen et al., 2001). Snow cover and depth in the Sierra Nevada of California vary dramatically in time and in space (from mountain ranges to ranges); but no ground-based measurements are available at rock glaciers. Snow models such as the Snow 
Data Assimilation System (SNODAS, http://www.nohrsc. nws.gov/nsa/) could be used to estimate the snow water equivalent at any given location, which is the key parameter to estimate the phase shift due to snow cover (Guneriussen et al., 2001). However, recent studies on improving the SNODAS model suggest that the model underestimates snow accumulation in lee sides of high cirques (Clow et al., 2012), exactly as in the Mount Gibbs high cirque. All these limitations make it a major challenge to accurately quantify the snow-related errors in our InSAR measurements. Practically, we observe little reduction in InSAR coherence in the winter interferograms as the L-band radar waves can easily penetrate through dry snow layer. Additionally, our inventory mapping uses satellite data acquired during snow-free seasons and is thus not subject to snow-related errors.

\subsection{Response of rock glaciers to climate warming: perspectives from InSAR}

The kinematic response of rock glaciers to climate warming is contentious. As air temperature increases, it is unclear whether rock glaciers will speed up due to accelerated degradation and melting and higher erosion rates (Gruber and Haeberli, 2007) or remain stable due to (1) thermal insulation by the protective rock debris matrix (Clark et al., 1994; Barsch, 1996; Millar et al., 2012) and (2) the local cooling effects caused by air circulation within rock matrix (Juliussen and Humlum, 2008; Leopold et al., 2011). The flow speed of some rock glaciers in the European Alps has accelerated in the last two decades or so (e.g. Kääb et al., 1997; Krainer and Mostler, 2000; Delaloye et al., 2008; Bodin et al., 2009). By contrast, in the Rocky Mountains of the USA, even observations longer than $30 \mathrm{yr}$ show no significant changes in rock glacier speed (Potter et al., 1998; Janke, 2005).

Practically, the ALOS PALSAR data are too short for monitoring long-term changes in rock glacier flow as the satellite was in operation for only five years from late 2006 to early 2011. Nonetheless, our study strongly suggests the necessity of considering possible aliasing due to seasonal variation when estimating long-term changes in flow speed. Possible interannual variation in surface flow, which has been observed in the European Alps (Nöetzli and Vonder Müehll, 2010), further complicates the estimate of long-term trends. In general, it requires a long time series with high temporal sampling rates to separate possible long-term changes in rock glacier kinematics from seasonal and interannual variability. Other satellites such as ERS-1/2 and Envisat have acquired longer time series of SAR data that are of potential for investigating the response of rock glaciers in the Sierra Nevada to climate changes in the last two decades. The major challenge of using C-band data for rock glacier studies, however, is the problem of InSAR phase decorrelation due to fast surface flow. We suggest a strategy to form a long time series of interferograms that have short time spans (e.g. 35 days for ERS-1/2). The ERS-1/2 tandem (1-day intervals) and ice-phase ( 3 day intervals) data that are commonly used for glacier studies may not be useful because rock glacier motion within one day is of the order of $1 \mathrm{~mm}$, too small to be reliably detected by InSAR. A few recently launched and future InSAR missions such as the TerraSAR-X, the CosmoSkymed, the ALOS-2, and the Sentinel Satellites will continue the observation period and provide denser temporal sampling rates (e.g. 11 days of TerraSAR-X) for monitoring rock glaciers.

\section{Conclusions}

In summary, we use InSAR data to compile an inventory of the flow speed, direction, and area of active motion at 59 rock glaciers in the Sierra Nevada. In the late summer of 2007, these rock glaciers moved at a mean speed of $55 \mathrm{~cm} \mathrm{yr}^{-1}$. Spatially, rock glaciers in the southern Sierra Nevada moved faster than those in the central area. Our regional-scale InSAR study provides a baseline map of the kinematic states and useful guidance for field investigations and for assessing the relationship of rock glacier flow with regional climate and local conditions.

We also conduct a detailed InSAR study to map the surface flow of the Mount Gibbs rock glacier. We find two fastmoving branches in the lower part of the rock glacier, collocated with surface flow lines. More interestingly, we observe a significant seasonal variability of surface speed, more than double in the fall from its minimum in the spring during the 2007-2008 season. Our findings suggest the necessity of a long time series with dense sampling to separate long-term changes in rock glacier kinematics associated with climate change from seasonal variations.

\section{Supplementary material related to this article is available online at: http://www.the-cryosphere.net/7/ 1109/2013/tc-7-1109-2013-supplement.zip.}

Acknowledgements. We thank R. P. Daanen, S. Gruber, O. Humlum, A. Kääb, and T. Strozzi for their careful and insightful reviews. B. Collins (US Geological Survey, Menlo Park) and T. R. Lauknes (Norut) reviewed an early version of this paper. The ALOS PALSAR data are copyrighted by the Japan Aerospace Exploration Agency and provided by the Alaska Satellite Facility, University of Alaska Fairbanks. Climatic data at Lee Vining, CA, are provided by the Western Regional Climate Center, NOAA. This research was supported primarily by the George Thompson Postdoctoral Fellowship to Lin Liu from the Department of Geophysics, Stanford University. Matlab and Generic Mapping Tools (Wessel and Smith, 1998) were used to make the figures.

Edited by: S. Gruber 


\section{References}

Arenson, L., Hoelzle, M., and Springman, S.: Borehole deformation measurements and internal structure of some rock glaciers in Switzerland, Permafrost Periglac., 13, 117-135, doi:10.1002/ppp.414, 2002.

Avian, M., Kellerer-Pirklbauer, A., and Bauer, A.: LiDAR for monitoring mass movements in permafrost environments at the cirque Hinteres Langtal, Austria, between 2000 and 2008, Nat. Hazards Earth Syst. Sci., 9, 1087-1094, doi:10.5194/nhess-9-1087-2009, 2009.

Barsch, D.: Nature and importance of mass-wasting by rock glaciers in alpine permafrost environments, Earth Surf. Processes, 2, 231245, doi:10.1002/esp.3290020213, 1977.

Barsch, D.: Rockglaciers: Indicators for the Present and Former Geoecology in High Mountain Environments, Springer, Berlin, 1996.

Berardino, P., Fornaro, G., Lanari, R., and Sansosti, E.: A new algorithm for surface deformation monitoring based on small baseline differential SAR interferograms, IEEE T. Geosci. Remote, 40, 2375-2383, doi:10.1109/TGRS.2002.803792, 2002.

Berger, J., Krainer, K., and Mostler, W.: Dynamics of an active rock glacier (Ötztal Alps, Austria), Quaternary Res., 62, 233242, doi:10.1016/j.yqres.2004.07.002, 2004.

Berthling, I., Etzelmüller, B., Eiken, T., and Sollid, J. L.: Rock glaciers on Prins Karls Forland, Svalbard, I: internal structure, flow velocity and morphology, Permafrost Periglac., 9, 135145, doi:10.1002/(SICI)1099-1530(199804/06)9:2<135::AIDPPP284>3.0.CO;2-R, 1998.

Bodin, X., Thibert, E., Fabre, D., Ribolini, A., Schoeneich, P., Francou, B., Reynaud, L., and Fort, M.: Two decades of responses (1986-2006) to climate by the Laurichard rock glacier, French Alps, Permafrost Periglac., 20, 331-344, doi:10.1002/ppp.665, 2009.

Brenning, A.: Geomorphological, hydrological and climatic significance of rock glaciers in the Andes of Central Chile (33-35 $\left.{ }^{\circ} \mathrm{S}\right)$, Permafrost Periglac., 16, 231-240, doi:10.1002/ppp.528, 2005.

Burger, K. C., Degenhardt Jr., J. J., and Giardino, J. R.: Engineering geomorphology of rock glaciers, Geomorphology, 31, 93-132, doi:10.1016/S0169-555X(99)00074-4, 1999.

Chen, C. and Zebker, H.: Phase unwrapping for large SAR interferograms: statistical segmentation and generalized network models, IEEE T. Geosci. Remote, 40, 1709-1719, doi:10.1109/TGRS.2002.802453, 2002.

Clark, D. H. and Gillespie, A. R.: Timing and significance of Lateglacial and Holocene cirque glaciation in the Sierra Nevada, California, Quatern. Int., 38-39, 21-38, doi:10.1016/S10406182(96)00024-9, 1997.

Clark, D. H., Clark, M. M., and Gillespie, A. R.: Debris-covered glaciers in the Sierra Nevada, California, and their implications for snowline reconstructions, Quaternary Res., 41, 139153, doi:10.1006/qres.1994.1016, 1994.

Clow, D. W., Nanus, L., Verdin, K. L., and Schmidt, J.: Evaluation of SNODAS snow depth and snow water equivalent estimates for the Colorado Rocky Mountains, USA, Hydrol. Process., 26, 2583-2591, doi:10.1002/hyp.9385, 2012.

Croce, F. A. and Milana, J. P.: Internal structure and behaviour of a rock glacier in the Arid Andes of Argentina, Permafrost Periglac., 13, 289-299, doi:10.1002/ppp.431, 2002.
Daly, C., Neilson, R. P., and Phillips, D. L.: A statisticaltopographic model for mapping climatological precipitation over mountainous terrain, J. Appl. Meteorol., 33, 140-158, doi:10.1175/1520-0450(1994)033<0140:ASTMFM > 2.0.CO;2, 1994.

Degenhardt Jr., J. J.: Development of tongue-shaped and multilobate rock glaciers in alpine environments - interpretations from ground penetrating radar surveys, Geomorphology, 109, 94-107, doi:10.1016/j.geomorph.2009.02.020, 2009.

Delaloye, R., Perruchoud, E., Avian, M., Kaufmann, V., Bodin, X., Hausmann, H., Ikeda, A., Kääb, A., Kellerer-Pirklbauer, A., Krainer, K., Lambiel, C., Mihajlovic, D., Staub, B., Roer, I., and Thibert, E.: Recent Interannual variations of rockglaciers creep in the European Alps, in: Proceedings of the 9th International Conference on Permafrost, Fairbanks, Alaska, 2008.

Delaloye, R., Lambiel, C., and Gärtner-Roer, I.: Overview of rock glacier kinematics research in the Swiss Alps, Geogr. Helv., 65, 135-145, doi:10.5194/gh-65-135-2010, 2010.

Gesch, D., Oimoen, M., Greenlee, S., Nelson, C., Steuck, M., and Tyler, D.: The national elevation dataset, Photogramm. Eng. Rem. S., 68, 5-11, 2002.

Gruber, S. and Haeberli, W.: Permafrost in steep bedrock slopes and its temperature-related destabilization following climate change, J. Geophys. Res., 112, F02S18, doi:10.1029/2006JF000547, 2007.

Guneriussen, T., Hogda, K., Johnsen, H., and Lauknes, I.: InSAR for estimation of changes in snow water equivalent of dry snow, IEEE T. Geosci. Remote, 39, 2101-2108, doi:10.1109/36.957273, 2001.

Haeberli, W.: Creep of mountain permafrost: internal structure and flow of alpine rock glaciers, Mit. Vers. Was., 77, 5-142, 1985.

Haeberli, W., Kääb, A., Wagner, S., Mühll, D., Geissler, P., Haas, J., Glatzel-Mattheier, H., and Wagenbach, D.: Pollen analysis and ${ }^{14} \mathrm{C}$ age of moss remains in a permafrost core recovered from the active rock glacier Murtèl-Corvatsch, Swiss Alps: geomorphological and glaciological implications, J. Glaciol., 45, 1-8, 1999.

Haeberli, W., Hallet, B., Arenson, L., Elconin, R., Humlum, O., Kääb, A., Kaufmann, V., Ladanyi, B., Matsuoka, N., Springman, S., and Mühll, D. V.: Permafrost creep and rock glacier dynamics, Permafrost Periglac., 17, 189-214, doi:10.1002/ppp.561, 2006.

Harrison, S., Whalley, B., and Anderson, E.: Relict rock glaciers and protalus lobes in the British Isles: implications for Late Pleistocene mountain geomorphology and palaeoclimate, J. Quaternary Sci., 23, 287-304, doi:10.1002/jqs.1148, 2008.

Humlum, O.: The climatic significance of rock glaciers, Permafrost Periglac., 9, 375-395, doi:10.1002/(SICI)10991530(199810/12)9:4<375::AID-PPP301>3.0.CO;2-0, 1998.

Humlum, O.: The geomorphic significance of rock glaciers: estimates of rock glacier debris volumes and headwall recession rates in West Greenland, Geomorphology, 35, 41-67, doi:10.1016/S0169-555X(00)00022-2, 2000.

Ikeda, A., Matsuoka, N., and Kääb, A.: Fast deformation of perennially frozen debris in a warm rock glacier in the Swiss Alps: an effect of liquid water, J. Geophys. Res., 113, F01021, doi:10.1029/2007JF000859, 2008.

Isaksen, K., Ødegård, R. S., Eiken, T., and Sollid, J. L.: Composition, flow and development of two tongue-shaped rock 
glaciers in the permafrost of Svalbard, Permafrost Periglac., 11, 241-257, doi:10.1002/1099-1530(200007/09)11:3<241::AIDPPP358>3.0.CO;2-A, 2000.

Janke, J.: Long-term flow measurements (1961-2002) of the Arapaho, Taylor, and Fair rock glaciers, Front Range, Colorado, Phys. Geogr., 26, 313-336, doi:10.2747/0272-3646.26.4.313, 2005.

Juliussen, H. and Humlum, O.: Thermal regime of openwork block fields on the mountains Elgåhogna and Sølen, central-eastern Norway, Permafrost Periglac., 19, 1-18, doi:10.1002/ppp.607, 2008.

Kääb, A.: Monitoring high-mountain terrain deformation from repeated air- and spaceborne optical data: examples using digital aerial imagery and ASTER data, ISPRS J. Photogramm., 57, 39 52, doi:10.1016/S0924-2716(02)00114-4, 2002.

Kääb, A., Haeberli, W., and Gudmundsson, G. H.: Analysing the creep of mountain permafrost using high precision aerial photogrammetry: 25 years of monitoring Gruben rock glacier, Swiss Alps, Permafrost Periglac., 8, 409-426, doi:10.1002/(SICI)10991530(199710/12)8:4<409::AID-PPP267>3.0.CO;2-C, 1997.

Kääb, A., Frauenfelder, R., and Roer, I.: On the response of rockglacier creep to surface temperature increase, Global Planet. Change, 56, 172-187, doi:10.1016/j.gloplacha.2006.07.005, 2007.

Kenyi, L. and Kaufmann, V.: Estimation of rock glacier surface deformation using SAR interferometry data, IEEE T. Geosci. Remote, 41, 1512-1515, doi:10.1109/TGRS.2003.811996, 2003.

Kistler, R. W.: Geologic map of the Mono Craters quadrangle, Mono and Tuolumne counties, California, Map GQ-462, Tech. rep., US Geological Survey, 1966.

Konrad, S. K., Humphrey, N. F., Steig, E. J., Clark, D. H., Potter, N., and Pfeffer, W. T.: Rock glacier dynamics and paleoclimatic implications, Geology, 27, 1131-1134, 1999.

Krainer, K. and Mostler, W.: Reichenkar rock glacier: a glacier derived debris-ice system in the western Stubai Alps, Austria, Permafrost Periglac., 11, 267-275, doi:10.1002/10991530(200007/09)11:3<267::AID-PPP350>3.0.CO;2-E, 2000.

Lambiel, C. and Delaloye, R.: Contribution of real-time kinematic GPS in the study of creeping mountain permafrost: examples from the Western Swiss Alps, Permafrost Periglac., 15, 229-241, doi:10.1002/ppp.496, 2004

Leopold, M., Williams, M., Caine, N., Völkel, J., and Dethier, D.: Internal structure of the Green Lake 5 rock glacier, Colorado Front Range, USA, Permafrost Periglac., 22, 107-119, doi:10.1002/ppp.706, 2011.

Limpach, P., Geiger, A., Beutel, J., Buchli, B., Wirz, V., and Gruber, S.: Permanent monitoring of rock glaciers with low-cost GPS, in: 9th Swiss Geoscience Meeting, 273-273, 2011.

Lundquist, J. D. and Cayan, D. R.: Surface temperature patterns in complex terrain: daily variations and long-term change in the central Sierra Nevada, California, J. Geophys. Res., 112, D11124, doi:10.1029/2006JD007561, 2007.

Millar, C. I. and Westfall, R. D.: Rock glaciers and related periglacial landforms in the Sierra Nevada, CA, USA; inventory, distribution and climatic relationships, Quatern. Int., 188, 90104, doi:10.1016/j.quaint.2007.06.004, available at: http://nsidc. org/data/ggd652.html, 2008.
Millar, C. I., Westfall, R. D., and Delany, D. L.: Thermal and hydrologic attributes of rock glaciers and periglacial talus landforms, Sierra Nevada, California, USA, Quatern. Int., doi:10.1016/j.quaint.2012.07.019, in press, 2012.

Nagler, T., Mayer, C., and Rott, H.: Feasibility of DINSAR for mapping complex motion fields of alpine ice- and rock-glaciers, in: Retrieval of Bio- and Geo-Physical Parameters from SAR Data for Land Applications, edited by: Wilson, A. and Quegan, S., Vol. 475 of ESA Special Publication, 377-382, 2002.

Nöetzli, J. and Vonder Müehll, D. (Eds.): Permafrost in Switzerland 2006/2007 and 2007/2008, Glaciological Report (Permafrost), The Cryospheric Commission of the Swiss Academy of Sciences, 2010.

Perruchoud, E. and Delaloye, R.: Short-term changes in surface velocities on the Becs-de-Bosson rock glacier (western Swiss Alps), in: Proceedings of the 9th International Symposium on High Mountain Remote Sensing Cartography (HMRSC-IX), vol. 43, 14-15, 2007.

Potter, N. J., Steig, E. J., Clark, D. H., Speece, M. A., Clark, G. M., and Updike, A. B.: Galena Creek rock glacier revisited: new observations on an old controversy, Geogr. Ann. A, 80, 251-265, 1998.

Rignot, E., Hallet, B., and Fountain, A.: Rock glacier surface motion in Beacon Valley, Antarctica, from syntheticaperture radar interferometry, Geophys. Res. Lett., 29, 1607, doi:10.1029/2001GL013494, 2002.

Roer, I., Kääb, A., and Dikau, R.: Rockglacier kinematics derived from small-scale aerial photography and digital airborne pushbroom imagery, Zeitschriftfür Geomorphology N.F., 49, 73-87, 2005.

Rott, H. and Siegel, A.: Analysis of mass movements in alpine terrain by means of SAR interferometry, in: Geoscience and Remote Sensing Symposium, 1999, IGARSS '99 Proceedings, IEEE 1999 International, vol. 4, 1933-1936, doi:10.1109/IGARSS.1999.774991, 1999.

Serreze, M. C., Clark, M. P., Armstrong, R. L., McGinnis, D. A., and Pulwarty, R. S.: Characteristics of the western United States snowpack from snowpack telemetry (SNOTEL) data, Water Resour. Res., 35, 2145-2160, doi:10.1029/1999WR900090, 1999.

Strozzi, T., Kääb, A., and Frauenfelder, R.: Detecting and quantifying mountain permafrost creep from in situ inventory, space-borne radar interferometry and airborne digital photogrammetry, Int. J. Remote Sens., 25, 2919-2931, doi:10.1080/0143116042000192330, 2004.

Wagner, S.: Creep of alpine permafrost, investigated on the murtel rock glacier, Permafrost Periglac., 3, 157-162, doi:10.1002/ppp.3430030214, 1992.

Wahrhaftig, C. and Cox, A.: Rock glaciers in the Alaska range, Geol. Soc. Am. Bull., 70, 383-436, 1959.

Wessel, P. and Smith, W. H. F.: New, improved version of generic mapping tools released, EOS T. Am. Geophys. Un., 79, 579-579, doi:10.1029/98EO00426, 1998.

Zebker, H. A. and Villasenor, J.: Decorrelation in interferometric radar echoes, IEEE T. Geosci. Remote, 30, 950-959, 1992.

Zebker, H., Hensley, S., Shanker, P., and Wortham, C.: Geodetically Accurate InSAR Data Processor, IEEE T. Geosci. Remote, 48, 4309-4321, doi:10.1109/TGRS.2010.2051333, 2010. 